\section{WHERE OLIVES GROW}

In the wide valley of San Fernando, down by the crumbling mission of San Diegc; or in the shadow of the picturesque pile of Santa Barbara the stroller finds some of the oldest olive groves in California. They were planted by the old padres, inspired by the old and true Italian proverb, "An olive orchard is a gold mine on the face of the earth plants for the centuries a perpetual income." Whether it is the associations or the charm of the climate, that is one of eternal summer so far as real winter is concerned, there is a fuscination about its culture aside from the merely commercial reasons. We see the old grove at San Diego from the mesa on which stands the fast-crumbling mission. It lies in the valley against low hills through which arroyos have broken. Along this old King's Highway are some of the oldest date palms in America, and among them is a modern windmill startling in its incongruity.

There is something particularly attractive about the olive tree; its vary shape tells of thrift; its upright growth, graceful and pointed leaves, olive-hued now, but turned by the gentle wind, glisten like silver. It is generally supposed that the home of the tree was in Italy, where it has been known for ages, and where the growth is so slow that it is a common saying that a man plants olives for his grandchildren; but on the foothills near Elizabeth lake a wild olive has been early Californians because it came into early bearing and practically never died. The old trees of san Fernando, which have been deserted and neglected fo seventv-five years, are now being cared for, and are rapidly throwing out branches and assuming their normal shape and beauty, and bid fair to equal the famous trees of Europe and Asia, which have been bearing fruit for one thousand years.

The enthusiast, if he is the man to succeed, does not

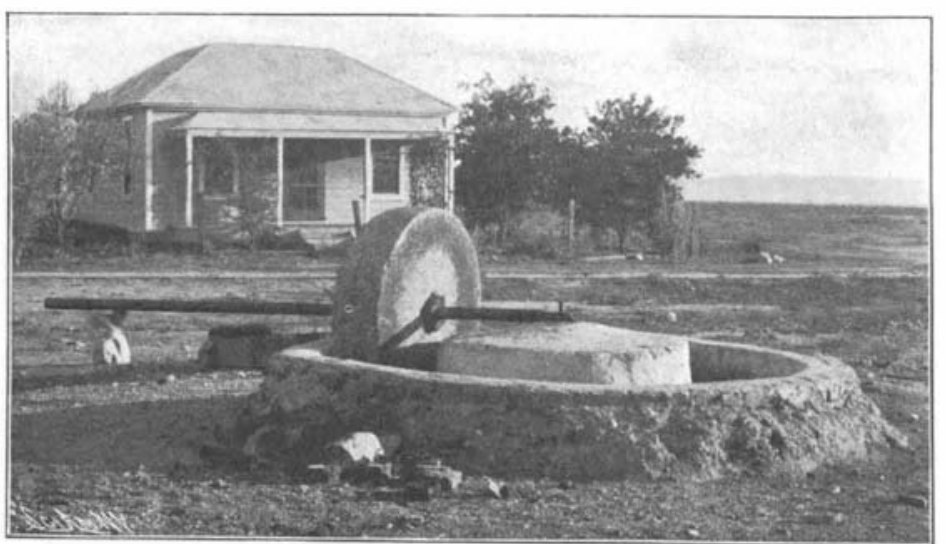

AN OL D MILL AT SAN FRANCISCO.

come to California to sit in the sun and watch things grow, but comes prepared to concentrate all his intelligence upon the work in hand. The successful culture of the olive, or any other fruit, in California require intelligence and work as elsewhere, despite the fact that nature invites, indeed urges, one to rest by the wayside.

It is the land of dolce for niente. but not to the Successful orchardist; he must be a man o and energy and eternal vigilance his watchword. Having secured his land, he buys from some re liable dealer cuttings taken from gcod, sound trees. These are three-fourths of an inch in diameter and two-thirds of a foot in length-

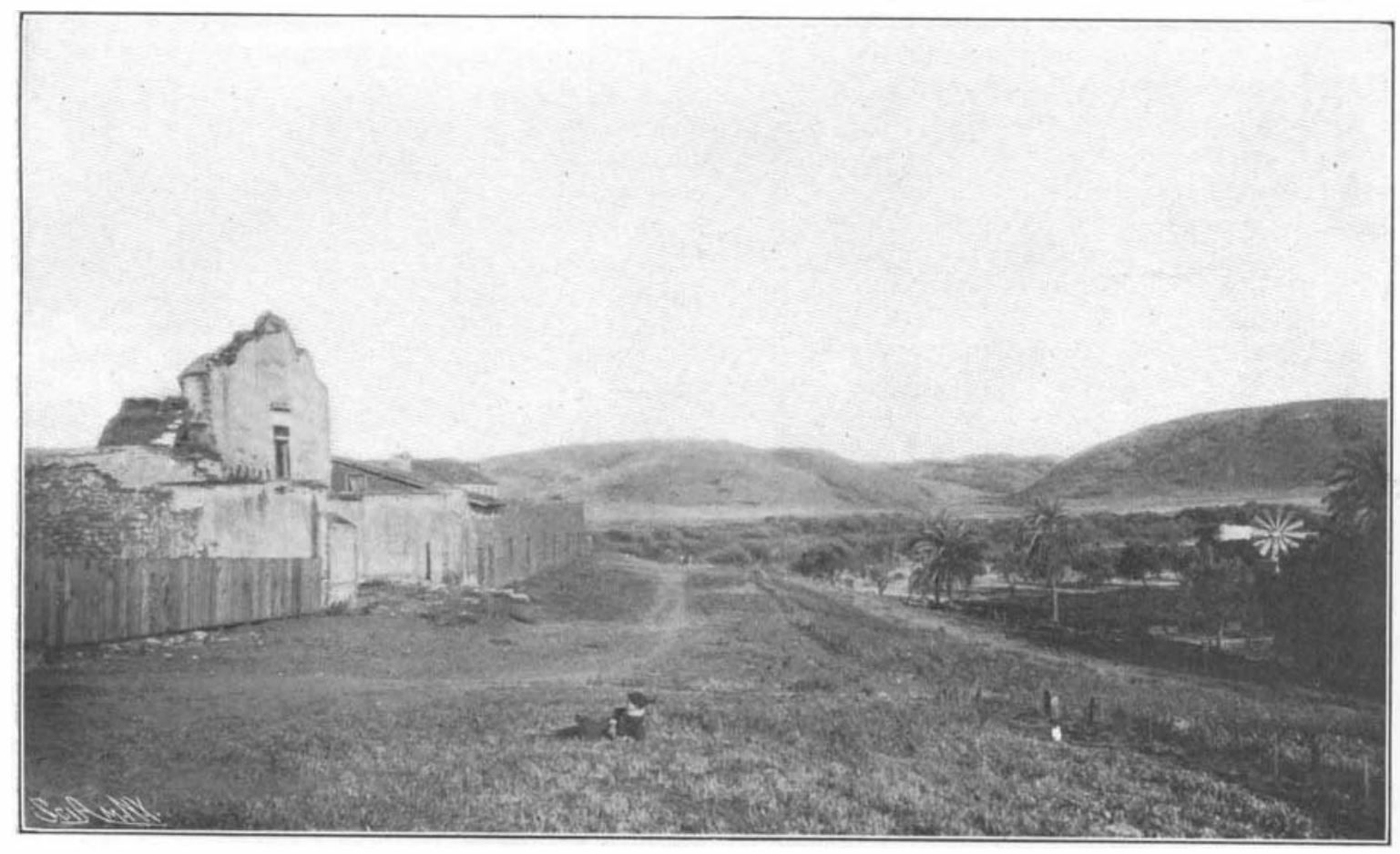

SAN DIEGO MISSION WITH OLIVE ORCHARD AND DATE PALMS. slender material one might think from which to produce a bearing tree in four years. These cutting have been taken from the parent tree in December or January, and are planted in rows in sandy soil being replanted permanently in February and March at a distance of about twenty feet apart. These will drow re of about twenty feet apart. These is kept well turned, the bush then being trimmed into a tree by cutting all the shoots but one, and in succeeding years the growe watches the tree and prunes it, with the idea in view of making a lusty tree. In four years some berries will be obtained, and the orchard ist is delighted at the luxuriant growth and the rich green olives, which hang so gracefully, but yet not sufficiently abundant to be of commercial value. In the sixth year the trees should produce thirty gallons each, and in eight years the grower finds himself in possession of a beautiful and productive grove. The trees have grown so wide that they fill the entire space and meet, and each tree under the most favorable conditions should produce forty gallons of clives. The orchardist figures that with one hundred trees to an acre, and forty gallons per tree, he will have four thousand gallons; but there are pests and other enemies which materially reduce this estimate. Indeed, if the grove produces a fourth of this, he is doing well.

In November, when the first rains come, the olives ripen, and as soon as the berries begin to turn purple the picking begins; and if five hundred acres have

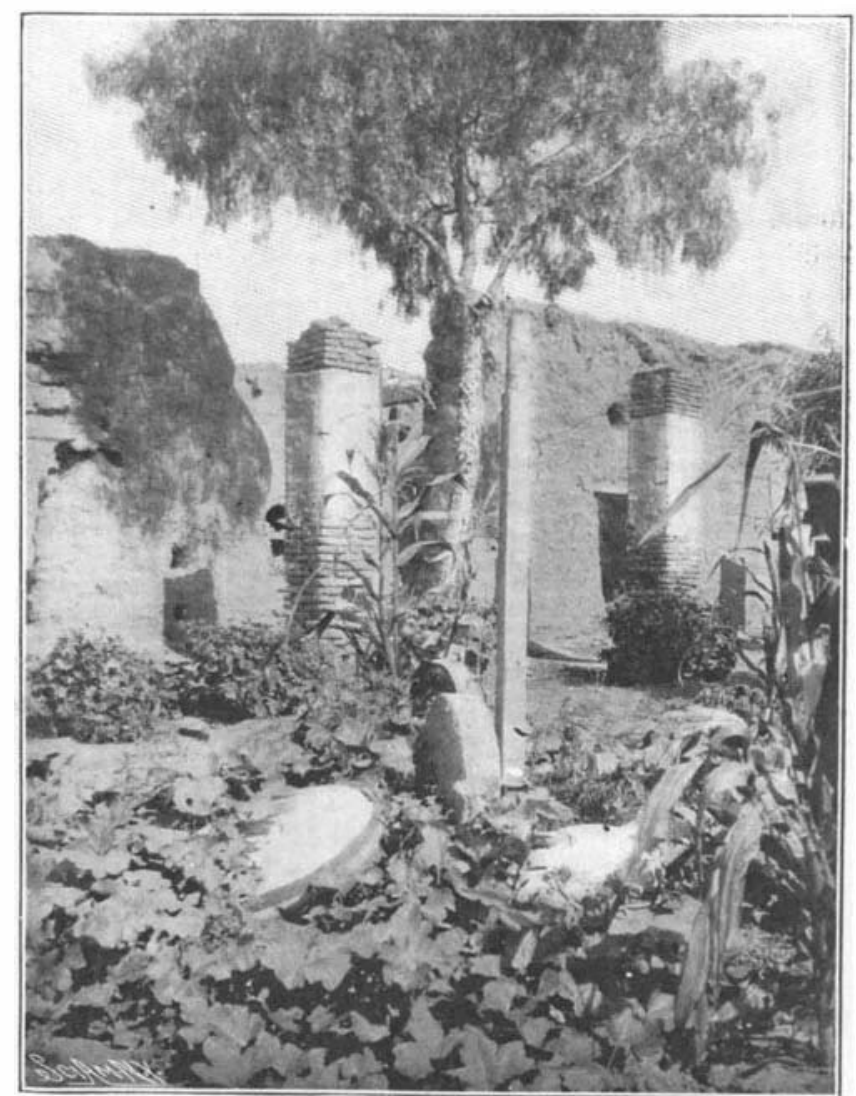

THE OLD OLIVE MILI AT SAN JOAN CAPISTRANO.

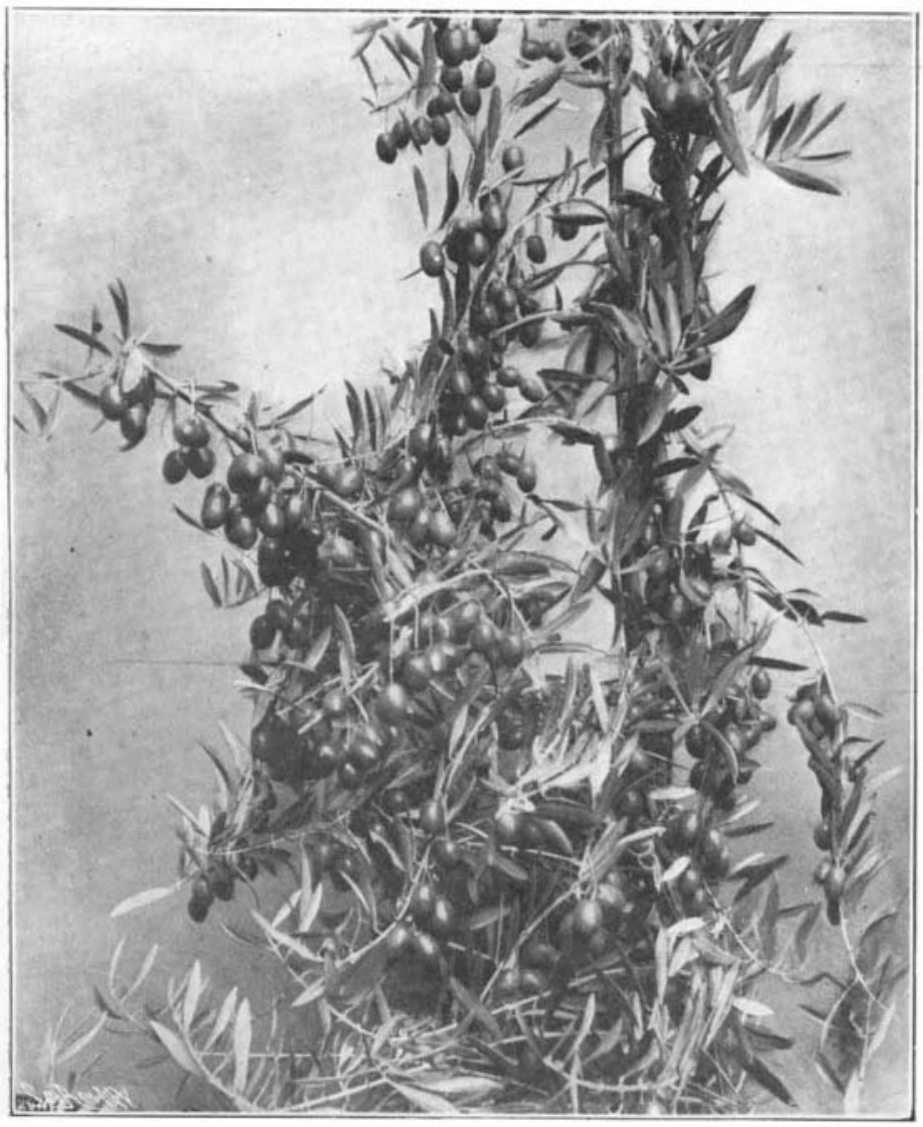

califoria olives.

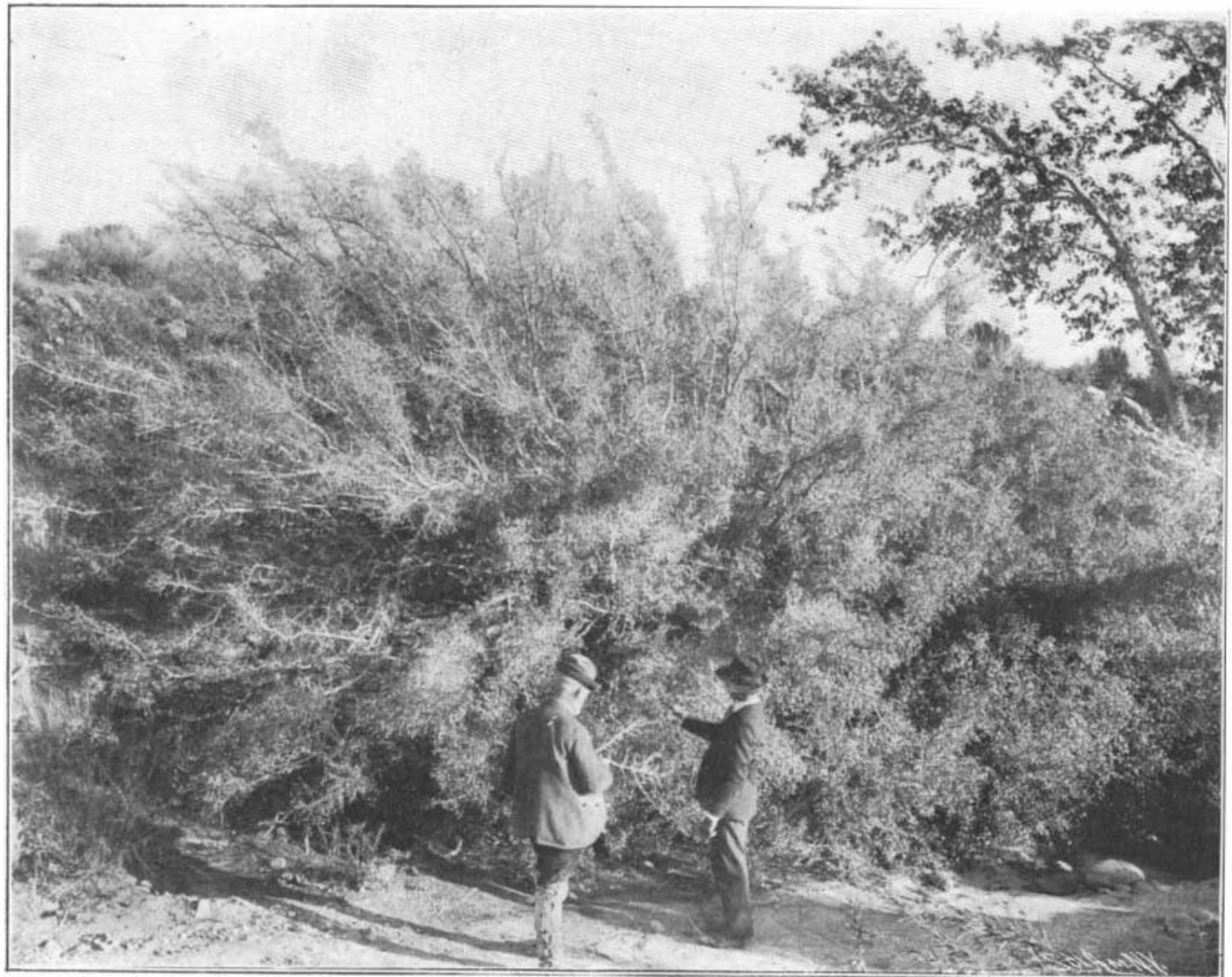

WILD OLIVE TREES AT LANCASTER, CAC. 
and others may be seen on the ground. Each picker carries a canvas open bag suspended in front of him about the neck, and a good picker should pick four hundred pounds per day. Some use ladders; others pick from platforms on the wagons which are drive along. After the picking the olives are subjected to a drying or evaporating process, and now the orchardist is confronted with the most delicate part of his ist is confronted with the most delicate part of his
work, the making of olive oil. In the olden days the crusher or mill was a conspicuous feature of ever mission, and that of San Fernando is still in good coldition, while the ruin of the old mill of San Gabri is one of the points of interest in the San Gabrie Valley. The temperature of the drier is not over 130 deg., and so arranged that the work is completed in two days. The drier itself has a capacity equal to the production of the grove, that of one orchard being 500 square feet of surface, and holding about 2,000 nounds of olives; five pickers at 400 pounds a da keep it filled. The crusher is interesting. It resem bles a millstone, but rests on its edge, which is six inches broad and runs in a circular trough six feet across, made of cement. Its axis is a long pole whic is fastened to the center of the trough, at the opposit end of which is harnessed a horse, the motive power; in the old days several Indians performed the work

In such a mill, seemingly small for the purpose the product of an orchard of one thousand trees ca be crushed. The millstones differ in size, and in large orchards there are several. A building is generally erected over the crusher, and the horse work outside of it, as everything about the olive is kept as clean as possible. The olive pulp is taken from the crusher and massed in lumps or cakes about three feet square and three inches thick. The press resem bles a New England cider press, and two are required bles a New England cider press, and two are require
to press out one hundred gallons of oil a day. The entire process is interesting. The result from the press is run into tanks, where it remains for three readily recovered residuum in the press is put through a second crush ing and treated to a bath of hot water, by which large quantity of second-quality oil is produced, eve a third quality being made. The oil now obtained goes to the clarifier or filter, which is a series of boxes from five to seven in number, the bottom cov ered with fine cotton batting. Some use a series of metal boxes, one in the other, each having a wir sieve bottom, the oil dripping from one to the other and coming out pure and as beautiful as liquid amber. The majority of foreign or imported oils are adulterated and made up of cottonseed or hog's lard. The extent to which this is carried may be realized from the fact that the cottonseed exportations from $\mathrm{Ne}$ Orleans for this purpose in one year were sufficient to fill fifteen million oil bottles at a cost of ten cents per bottle.

The orchardist probably pickles and bottles a po tion of his crop, and in California there is an eve increasing demand for the ripe olive, which when cured is very dark and rich. In pickling, the olives are first placed in fresh water, which is changed daily for forty or fifty days, after which they are placed in salt brine to be changed several times, and finally placed in a brine the water of which has been boiled, and there are many variations from this which result in the attractive olive of commerce. The orchardist now has a fine producing grove, but his paths are not all coleur de rose, as while the olive can be said to be freer from pests than many other trees, yet succes is only attained at the price of eternal vigilance Nature is capricious, and does not always produce conditions perfectly favorable. A year of intense heat may come just at the wrong time, or a cold snap may literally nip the year's prospects in the bud, and early in his experience the orchardist is confronted with an army of pests which he must fight day and night. an army of pests which he must fight day and night. a glance at the authorities on the olive scale insec by whom we are told that one female will produce four thousand eggs, and that a single coccus will produce five generations, nearly six billion descendants; or at the end of a year, according to Lejourdan the progeny of a single female will be one billion billion. This is appalling, yet the world's supply of olive oil is kept up, and the pure oil of California olive oil is kept up, and the
leads in quality and return.

A new floating portoon dock is being constructed in Great Britain for Durban, South Africa. to replace the one which was recently wrecked on the rocks off the coast of Cape Colony, while en route from Eng. land to its destination. This new dock is to be much more powerful than the one which was wrecked, though it will be similar in construction. It will measure 475 feet over all-an increase of 110 feet over
the wrecked dock-while its lifting capacity will be the wrecked dock-while its lifting capacity will be
4,000 tons greater- $-8,500$ tons as compared with 4,500 4,000
tons.
The Pennsylvania Railroad has a contract to take all the cars which can be turned out by the Pressed Steel Car Company, between December 1, 1902, an June 1, 1903. The capacity of this plant is one hundred cars per day. This means an expenditure of $\$ 15,000,000$, and will increase the capacity of the Pennsylvania equipment by about $\mathbf{7 5 0 , 0 0 0}$ tons.

After having been extensively overhauled and renoated, the Hicks Locomotive and Car Works at Chicago Heights, Ill., is now in full operation. The improve ments consisted of replacing all the original buildings with a single exception with fine well-lighted and ventilated buildings. This concern is devoted almost exclusively to the repairing and rebuilding of heav and modern locomotives. The capacity of the work is at present 15 locomotives, 15 coaches and 200 handled at one time at the Hicks plant.

In connection with the speed trials of the new British cruiser "Drake," in which a speed of twenty-four knots was obtained while running at full speed, exper ments were carried out with a new type of propelle the blades of which are almost circular in shape, in stead of the present approach to the oval form. By this arrangement the screws obtain a more powerful grip of the water. Owing to the conspicuous success which attended the speed trials of the "Drake," since the maximum speed contracted for was only twentythree knots, it is proposed to carry out further tests with the propeller upon other vessels.

The Pennsylvania Railroad has been experimenting th a new style of track, which has been laid for purpose of making a practical test on the For Wayne Division, at Leetsdale, Pa. The tracks are aid on a pressed-steel girder of trough shape, and directly supporting each rail with channel spacers to maintain the gage and fastenings for the rail, whic do not require the use of bolts, wedges, or any other movable parts. This constitutes the rail in its en tirety, and although simple in construction, is effective in providing a solid track without the use of heavy allast, as is required by the wooden tie

The commission appointed by the French Admiralt to investigate the subject of water-tube boilers, to ascertain the best all-round boiler of this type for naval vessels, and to investigate the respective advantages of small-tube and large-tube boilers, has published its report. The commission recommend th adoption solely of large tubes for boilers fitted to battleships and armored cruisers. Experience has conclusively proved to the commission that the smal tube boiler, while it gives a higher evaporation per square foot of heating surface than the large-tube boiler, consumes far more fuel per unit of power while it is also more difficult to clean and repair the tubes. In this decision the commission is supporte by the results of the boilers of the "Jeanne d'Arc" and two other similar vessels. Two types of boiler and two other similar vessels. Two types of boiler being the most satisfactory water tubes, though in the case of the Belleville, economizers are deprecated. Either of these two types will be fitted in all future vessels, including those now under construction. It has furthermore been decided that in the full-powe and subsequent trials with only 75 per cent of the boilers in use, of vessels, the maximum fuel consump tion is to be $221 \%$ pounds of coal and $303 / 4$ pounds per square foot of grate per hour respectively.

$$
\text { The current supplement. }
$$

The current Stpplemerr, No. 1420, contains a not worthy'series of articles on widely different topic The salmon investigations of the steamer "Albatross" in Alaska are fully narrated by Commander Jefferso F. Moser, and are illustrated by many striking pic tures. Fred T. Jane presents another installment of the Naval War Game between the United States and Germany. In the present installment he tells of the severe defeat and destruction of the German fleet in the Far East. Emile Guarini gives an account of very novel way of solving the smoke problem. The article describes the method by which the smoke is not consumed, but is commercially utilized in the form of an enriched gas. J. D. Geddes writes on photography as applied to illustration and printing. Charles $C$. Drueding presents a plain, intelligent treatise on chamois skins. Ceylon tea is now almost as widely consumed as the tea of China and Japan. An article on the tea industry of Ceylon will, therefore, not be without interest. Prof. Asaph Hall, president of the American Association for the Advancement of Science. di inguished the world over for his astronomical work presents a scholarly paper on the science of astronomy. Prof. Wesley Mills, of McGill University, for a numblind in studied the behavior of animals totally bind in either one or both eyes. He summarizes $h$ temperature electro-chemistry by R. S. Hutton and J. E. Petavel is continued.
A patent has just been issued in the United States to Mr. I. M. Hunter for a coin-controlled X-ray machine for public use. The external appearance of the apparatus is similar to that of the automatic cinematograph machines so commonly seen on railway platforms and other places. The observer places coin in the slot, moves a lever, puts his hand, or whatever he wishes to examine, into a box without any sides, and looks down at it through a fluorescent screen which forms the top of the box. The coin, on being inserted, closes the primary circuit of an induction coil worked by a few dry cells, and the vacuum tube is in a position immediately below the object to be observed.

A novel way to get electricity for lighting a railway train is described by Cassier's Magazine. A dy namo is located on the engine, perhaps under th pilot. Power in driving it is derived from a rotary fan or windmill immediately above, under the headlight. As the locomotive travels at the rate of 20,30 and even 40 miles an hour, a breeze of corresponding velocity is developed. The current is conveyed to small accumulators under each car of the train. It may be assumed that when these are fully charged, the current is automatically cut off. Tests are said to have been made with an outfit of this kind, and the results are said also to have been encouraging, contrary to what one might be led to expect.

A short time ago the proposal was made and seriously entertained in some quarters to distribute Greenwich time to vessels at sea as well as inland by wireless telegraphy, and, according to our contemporary, Cosmos, Messrs. Burgos, a firm of clockmakers at Ocejos, have devised an apparatus for carrying out the distribution inland. A standard or primary clock determines the discharge of an oscillator at regula intervals. The local or secondary clocks have each an air wire to direct the electric waves on to a detector, which actuates a mechanism and corrects the hands on the dials. We are not aware that the above plan has been put into practice yet, nor is information available as to the results of experiments. The difficulty appears to be that other signals by wireless telegraphy will affect the clocks.

An automatic mechanism which is intended to register the number and class of passengers of a car, the distance ridden by each, the approximate time and place of ingress and egress of each, identifying the conducof the day or night and the approximate or minute the car, in order to obtain a true automatic register or record of the trip and the number of passengers carried independently of the co-operation and beyond the control of the conductor, is an invention for which Frederick W. Brooks of Brooklyn, N. Y., has obtained a patent. The apparatus takes its records in such manner that they may be used as laritern slides and projected on a screen. An automatic mechanism controls electric circuits and connections to operate a camera electrically, at such intervals or distances apart as may be desired by and in consequence of the revolution of the car wheels. The mechanism is arranged in such a manner that the intervals can be changed or adjusted at will. The camera is so adjusted as to photograph the interior or part of the interior of the car, the platform or platforms and side running boards, and any and all passengers that may come within it field. The camera is so connected with the electrical appliances of the car as to cut off objectionable or conflicting lights. The connections are all protected. The parts of the invention may be briefly summed up as follows: First, a device connected with and operated by the revolution of a wheel or axle of the car and an electrical connection by which the operations of the camera and registers and the distance between such operations are actuated and controlled; second, an electric current from any available source, preferably a battery, either primary or storage, situated in such connected by conductors with the above device, by which the circuit or circuits are opened or closed, the opening and closing of the electric currents being arranged to operate the camera or cameras, the registers, and the lighting and de-lighting of the car; third, method for automatically lighting the car in such por tions as are desired and means for shutting off conflicting or objectionable lights.

\section{A Correction.}

In the Sciextific Aniericax for February 14, there appears an article under the heading "Transportin Lumber Across Deep Gorges," in which credit for the design of the installation described is given to $\mathrm{Mr}$. Edward I. Parsons. We are informed that the system in question was really designed by Percy R. Stuart, of San Francisco, Cal., and we take this opportunity of giving to hlm the credit to which he is properly entitled. 